rence of circulating antibodies may be one of the reasons for adverse reactions to rifampicin, but it is probable that, in due course, other mechanisms will be shown to be involved. In the Hong Kong study a large programme of immunological and haematological investigations is in progress, among the aims being to identify patients likely to develop adverse reactions and to find ways of preventing such reactions. Clinically, in Hong Kong the problems presented by adverse reactions, as now managed, on intermittent rifampicin regimens are so far not substantially greater than those encountered on the standard reserve regimen, although purpura and the respiratory syndrome require special caution. Even the daily rifampicin regimen cannot be regarded as free from hazard.

In the final analysis a vital issue in the choice of the best failure regimen among those under study will be the relative therapeutic efficacy of the different regimens balanced against the incidence of adverse reactions during the whole period of treatment, and this will be reported on later. In the meantime, reports from other workers on their experience of managing adverse reactions in patients on intermittent rifampicin-containing regimens will be awaited with interest.

We are grateful to the Director of Medical and Health Services, Hong Kong (Dr. G. H. Choa) for permission to report these findings.

\section{References}

Batten, J. (1969). Tubercle, 50, 294.

Batten, J. (1970). Tubercle, 51, 95.

Bergamini, N., Binda, G., Ferrario, A., Fowst, G., and Pietra, V. (1971). Proceedings of the Symposium on Rifampicin, Prague, October 5-9, 1970, p. 152. Prague, Czechoslovak Medical Press.

Blajchman, M. A., Lowry, R. C., Pettit, J. E., and Stradling, P. (1970). British Medical fournal, 3, 24 . Bobrowitz, I. D., and Robins, D. E. (1967). American Review of Respiratory
Diseases, 96, 428.

British Tuberculosis Association (1963). Tubercle, 44, 195.
Canetti, G., Le Lirzin, M., Porven, G., Rist, N., and Grumbach, F. (1968), Tubercle, 49, 367.

Constans, P., Saint-Paul, M., Morin, Y., Bonnaud, G., and Bariety, M. (1969' Revue de la Tuberculose et de Pneumologie, 33, 97.

Decroir, (ن., et al. (1969). Revue de la Tuberculose et de Pneumologie, 33, 751.

Decroix, G., et al. (1971). Revue de la Tuberculose et de Pneumologie 35, 39.

Dickinson, J. M., Jacket, P. S., and Mitchison, D. A. (1972). American Review of Respiratory Diseases. In press.

Review of Respiratory Diseases. In press.
Dickinson, J. M., and Mitchison, D. A. (1970). Tubercle, 51, 82.

Eule, H. (1971). Committee on Treatment, 21st International Tuberculosis Conference, Moscow, 12-16 July, 1971 .

Farga, V. (1970a). Bulletin of the International Union Against Tuberculosis, 44,89 .

Farga, V. (1970b). Committee on Treatment, International Union Against Tuberculosis, 7-12 September, 1970, Ankara.

Ferguson, G. C. (1971). British Medical Fournal, 3, 638.

Fox, W. (1969). Tubercle, 50, Suppl. p. 55.

Fox, W. (1971). Postgraduate Medical fournal, 47, 729.

Furesz, S., Scotti, R., Pallanza, R., and Marpelli, E. (1967). ArzneimittelForschung, 17, 523.

Grumbach, F., Canetti, G., and Le Lirzin, M. (1969). Tubercle, 50, 280

Grumbach, F., Canetti, G., and Le Lirzin, M. (1970). Revue de la Tuberculose et de Pneumologie, 34,312 .

Grumbach, F., and Rist, N. (1967). Revue de la Tuberculose et de Pneumologie, 31, 749 .

International Union Against Tuberculosis (1968). Proceedings of the 19th International Tuberculosis Conference, October 3-7 1967, Amsterdam, p. 175. Amsterdam, Excerpa Medica.

Lees A. W., Allan, G. W., Smith, J., Tyrrell, W. F., and Fallon, R. J. (1971). Tubercle, 52, 182 .

Leibold, J. E. (1966). Annals of the Ne:y York Academy of Sciences, 135, 904 Lesobre, R., Ruffino, J., Teyssier, L., Archard, F., and Brefort, G. (1969). Revue de la Tuberculose et de Pneumologie, 33, 393.

Lucchesi, M., and Mancini, P. (1970). Antibiotica et Chemotherapia, 16, 431. Newman, R., Doster, B., Murray, F. T., and Ferebee, S. (1971). American Review of Respiratory Diseases, 103, 461.

Nitti, V. (1969). Antibiotica et Chemotherapia, 16, 1

Pines, A. (1971). British fournal of Diseases of the Chest, 65, 178.

Poole, G., Stradling, P., and Worlledge, S. (1971). British Medical fournal, 3, 343 .

Sepúlveda, R., et al. (1971). Revista Médica de Chile, 100, 934.

Tuberculosis Chemotherapy Centre, Madras. (1970). Bulletin of the World Health Organization, 43, 143.

Verbist, L. (1969). Acta Tuberculosea et Pneumologica Belgica, 60, 397.

Verbist, L., Gyselen, A., Lunduyt, van H., Mbete, S., and Darras, T. (1971) Proceedings of the Symposium on Rifampicin, Prague, October 5-9 1970, p. 104. Prague, Czechoslovak Medical Press.

Zierski, M. (1971). Proceedings of the Symposium on Rifampicin, Prague, Octoher 5-9 1970, p. 105. Prague, Czechoslovak Medical Press.

Zierski, M. (1972). British Medical fournal, 1, 183.

\title{
Total Body Potassium in Non-Dialysed and Dialysed Patients with Chronic Renal Failure
}

\author{
KEITH BODDY, PRISCILLA C. KING, ROBERT M. LINDSAY, JAMES D. BRIGGS, \\ JAMES F. WINCHESTER, ARTHUR C. KENNEDY
}

British Medical fournal, 1972, 1, 771-775

\section{Summary}

Total body potassium was studied in 33 patients with chronic renal failure, 18 of whom had been receiving regular dialysis therapy for 1 to 48 months. In nondialysed patients body potassium was not significantly different from normal in the group as a whole, but was significantly greater than normal in three patients, and significantly less than normal in two patients. In 14 of the dialysed patients, both as individuals and as a group,

\footnotetext{
Scottish (Universities) Research Reactor Centre, East Kilbride, Glasgow

KEITH BODDY, M.SC., PH.D., Senior Lecturer in Health Physics and Nuclear Medicine
}

PRISCILLA C. KING, M.SC., PH.D., Research Assistant

Royal Infirmary, Glasgow C.4

ROBERT M. LINDSAY, M.B., CH.B., M.R.C.P., Senior Registrar in Medicine JAMES F. WINCHESTER, M.B., CH.B., Senior House Officer in Medicine ARTHUR C. KENNEDY, M.D., F.R.C.P., Professor of Medicine

Western Infirmary, Glasgow W.1

JAMES D. BRIGGS, M.B., CH.B., M.R.C.P., Consultant Renal Physician body potassium was not significantly different from normal but in the remaining four it was less than normal.

Potassium transfer during dialysis was studied in two patients. Uptake by these two patients of ${ }^{4}{ }^{3} \mathrm{~K}$ added to the dialysate ( $1 \mathrm{mEq} \mathrm{K} /$ litre) was measured by whole-body monitoring. Transfer of administered ${ }^{4} \mathrm{~K}$ from the patients to the dialysate was measured by whole-body monitoring and by radioactive and chemical assay of the dialysate. A negative balance due to twice-weekly dialysis of 178 and $244 \mathrm{mEq} \mathrm{K}$ /week was found, which with weekly faecal and urine losses of 20-30 $\mathrm{mEq} K$ approximately equals the dietary intake of 210-315 $\mathbf{m E q} \mathbf{K}$.

\section{Introduction}

In non-dialysed patients with chronic renal failure, the 24-hour exchangeable body potassium was significantly lower than in control subjects (Moore et al., 1954). In seven out of eight patients with chronic renal failure, who were being treated with a Kiil dialyser using the same potassium concentration in the dialysate as in the present study ( $1 \mathrm{mEq} /$ litre), the 24-hour 
exchangeable body potassium was also significantly less than in controls (Seedat, 1969). However, it has been shown (Boddy et al., 1972a) that in patients with chronic renal failure equilibration between administered radioactive potassium and native potassium is incomplete at 24 hours after administration. Even after 64 hours the exchangeable potassium was a smaller fraction of the total body potassium than in controls. These findings suggested that exchangeable potassium might not be entirely reliable as an index of potassium status in this condition.

Three aspects of this problem were examined in the present study. Total body potassium was measured in patients with chronic renal failure who were not receiving regular dialysis treatment. Similar measurements were made in patients who had been receiving regular dialysis over periods ranging from 1 to 48 months. A limited study of bidirectional transfer of potassium between the dialysed patient and the dialysate was undertaken to relate the patients' total body potassium to the potassium balance.

\section{Patients and Methods}

Thirty-three patients with chronic renal failure, 18 of whom were being maintained by regular dialysis, were included in the study. Relevant clinical data are summarized in Tables I and II. The non-dialysed patients were on a low-protein diet with potassium content estimated from the diet of between 40 and $100 \mathrm{mEq} /$ day (Table I). The dialysed patients each received two 10-hour haemodialyses per week using a $1-\mathrm{m}^{2}$ Cellophane

TABLE I-Clinical Data of Non-dialysed Patients

\begin{tabular}{|c|c|c|c|c|c|c|c|}
\hline \multirow[t]{2}{*}{$\begin{array}{l}\text { Case } \\
\text { No. }\end{array}$} & \multirow[t]{2}{*}{$\begin{array}{l}\text { Age } \\
\text { and } \\
\text { Sex }\end{array}$} & \multirow[t]{2}{*}{ Diagnosis } & \multirow{2}{*}{ 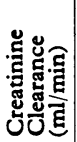 } & \multirow{2}{*}{ 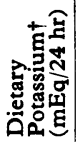 } & \multirow{2}{*}{ 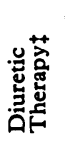 } & \multicolumn{2}{|c|}{$\begin{array}{c}\text { Total } \\
\text { Body } \\
\text { Potassium } \\
(\mathrm{mEq})\end{array}$} \\
\hline & & & & & & Measured & Predicted \\
\hline $\begin{array}{r}1 \\
2 \\
3 \\
4 \\
5 \\
6 \\
7 \\
7 \\
8 \\
9 \\
10 \\
11 \\
12 \\
13 \\
14 \\
15\end{array}$ & $\begin{array}{l}49 \mathrm{M} . \\
43 \mathrm{M} . \\
34 \mathrm{M} . \\
47 \mathrm{M} . \\
75 \mathrm{M} . \\
54 \mathrm{~F} . \\
24 \mathrm{~F} . \\
23 \mathrm{~F} . \\
43 \mathrm{~F} . \\
61 \mathrm{~F} . \\
19 \mathrm{~F} . \\
58 \mathrm{~F} . \\
38 \mathrm{~F} . \\
39 \mathrm{~F} . \\
51 \mathrm{~F} .\end{array}$ & $\begin{array}{l}\text { Polycystic } \\
\text { G.N. } \\
\text { G.N. } \\
\text { Polycystic } \\
\text { C.P.N.* } \\
\text { Polycystic } \\
\text { C.P.N. } \\
\text { C.P.N. } \\
\text { C.P.N. } \\
\text { C.P.N. } \\
\text { C.P.N. } \\
\text { C.P.N. } \\
\text { Polycystic } \\
\text { H.N. } \\
\text { C.P.N. }\end{array}$ & $\begin{array}{r}11 \cdot 0 \\
6.5 \\
<5 \\
40 \\
20 \\
7.4 \\
<5 \\
<5 \\
11.0 \\
14.0 \\
10.0 \\
<5 \\
12 \\
17.2\end{array}$ & $\begin{array}{r}53 \\
40 \\
56 \\
100 \\
70 \\
56 \\
56 \\
53 \\
53 \\
53 \\
53 \\
56 \\
53 \\
70 \\
70\end{array}$ & $\begin{array}{l}0 \\
++ \\
+ \\
+ \\
0 \\
0 \\
0 \\
0 \\
++ \\
0 \\
0 \\
0 \\
0 \\
0 \\
0\end{array}$ & $\begin{array}{l}3,200 \\
3,276 \\
4,384 \\
3,555 \\
2,867 \\
2,210(2,292) \\
2,865(2,803) \\
2,512 \\
2,716 \\
2,015 \\
2,499 \\
1,417 \\
1,944 \\
2,407 \\
2,215\end{array}$ & $\begin{array}{l}3,402 \\
3,399 \\
3,757 \\
3,911 \\
3,468 \\
1,775(1,798) \\
2,437(2,445) \\
2,409 \\
2,432 \\
1,911 \\
2,657 \\
2,067 \\
1,964 \\
2,297 \\
2,041\end{array}$ \\
\hline
\end{tabular}

G.N. = Chronic glomerulonephritis. C.P.N. = Chronic pyelonephritis. H.N. = Hydronephrosis.

* Mean dietary potassium estimated for minimum of 3 months.

$\$ 0=$ No diuretics. $+=$ Bendrofluazide $5-10 \mathrm{mg} / \mathrm{day}$, frusemide $40-120 \mathrm{mg} /$ day. $++=$ Frusemide $120-500 \mathrm{mg} /$ day.

TABLE II-Clinical Data-Regular Dialysis Treatment Patients

\begin{tabular}{|c|c|c|c|c|c|}
\hline \multirow[t]{2}{*}{$\begin{array}{l}\text { Case } \\
\text { No. }\end{array}$} & \multirow[t]{2}{*}{ Age and Sex } & \multirow[t]{2}{*}{ Diagnosis } & \multirow{2}{*}{$\begin{array}{c}\text { Duration of } \\
\text { Dialysis Treatment } \\
\text { (Months) }\end{array}$} & \multicolumn{2}{|c|}{$\begin{array}{c}\text { Total Body } \\
\text { Potassium (mEq) }\end{array}$} \\
\hline & & & & Measured & Predicted \\
\hline $\begin{array}{l}16 \\
17 \\
18 \\
19 \\
20 \\
21 \\
22 \\
23 \\
24 \\
25 \\
26 \\
27 \\
28 \\
29 \\
30 \\
31 \\
32 \\
33\end{array}$ & $\begin{array}{l}39 \mathrm{M} . \\
29 \mathrm{M} . \\
43 \mathrm{M} . \\
41 \mathrm{M} . \\
39 \mathrm{M} . \\
23 \mathrm{M} . \\
27 \mathrm{M} . \\
26 \mathrm{M} . \\
34 \mathrm{M} . \\
40 \mathrm{M} . \\
33 \mathrm{M} . \\
26 \mathrm{M} . \\
40 \mathrm{M} . \\
19 \mathrm{M} . \\
38 \mathrm{~F} . \\
31 \mathrm{~F} . \\
31 \mathrm{~F} . \\
20 \mathrm{~F} .\end{array}$ & $\begin{array}{l}\text { C.P.N. } \\
\text { G.N. } \\
\text { G.N. } \\
\text { G.N. } \\
\text { G.N. } \\
\text { Hypoplasia } \\
\text { G.N. } \\
\text { G.N. } \\
\text { G.N. } \\
\text { G.N. } \\
\text { G.N. } \\
\text { C.P.N.** } \\
\text { G.N. } \\
\text { G.N. } \\
\text { G.N. } \\
\text { C.P.N. } \\
\text { C.P.N. } \\
\text { G.N. }\end{array}$ & $\begin{array}{r}2 \\
12 \\
14 \\
48 \\
48 \\
46 \\
30 \\
3 \\
1 \\
20 \\
18 \\
19 \\
8 \\
11 \\
19 \\
26 \\
12 \\
16\end{array}$ & $\begin{array}{l}2,844 \\
3,622 \\
3,588 \\
2,928 \\
2,668 \\
3,041 \\
3,532 \\
3,386 \\
3,169 \\
3,079 \\
2,949 \\
3,555 \\
2,893 \\
1,967 \\
2,018 \\
2,056 \\
2,154 \\
2,215\end{array}$ & $\begin{array}{l}3,276 \\
3,678 \\
3,711 \\
3,044 \\
2,747 \\
3,200 \\
3,317 \\
3,629 \\
2,982 \\
2,734 \\
3,468 \\
3,813 \\
3,302 \\
2,780 \\
2,450 \\
2,356 \\
2,373 \\
2,606\end{array}$ \\
\hline
\end{tabular}

G.N. = Chronic glomerulonephritis. C.P.N. = Chronic pyelonephritis. Creatinine clearance in all patients $<5 \mathrm{ml} / \mathrm{min}$. coil (Ultra-Flo 100 Travenol) in an R.S.P. dialyser (Travenol). The duration of regular dialysis treatment for each patient is indicated in Table II. The potassium concentration of the dialysate was $1 \mathrm{mEq} / \mathrm{l}$. The patients were on a $60-\mathrm{g}$ protein diet with an expected potassium content of $30 \mathrm{mEq} /$ day. In practice, however, direct examination of the diet itself suggested that the potassium content of the outpatient diet ranged from 30 to $\mathbf{4 5}$ $\mathrm{mEq} /$ day.

Total body potassium was measured in all patients with the Merlin mobile whole-body radioactivity monitor (Boddy, 1967) and the measurement was repeated in two of the non-dialysed patients after an interval of three to four months. The counting rate from the naturally occurring radioactive isotope ${ }^{40} \mathrm{~K}$, which is a constant fraction of the total body potassium, was expressed as $\mathrm{mEq}$ of potassium; the calibration equation derived in a previous study was used (Boddy et al., 1971). The expected total body content of potassium was estimated from relationships obtained in control subjects (Boddy et al., 1972b) relating body potassium to the subjects' weight, height, and age and to height and age only.

A schematic outline of the study of potassium kinetics is given in Fig. 1. In two of these patients the total body potassium

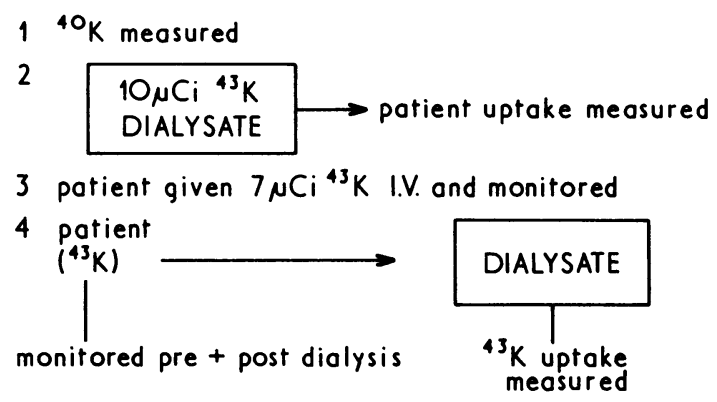

FIG. 1-Dialysis potassium kinetics-methodology.

was measured shortly before dialysis. Then $10 \mu \mathrm{Ci}{ }^{4}{ }^{3} \mathrm{~K}$ was mixed uniformly with the dialysate. The patients were monitored after dialysis and the counting rate due to ${ }^{43} \mathrm{~K}$ taken up from the dialysate was obtained. Each patient was then given 7 $\mu \mathrm{Ci}^{4}{ }^{3} \mathrm{~K}$ intravenously and was re-monitored. The counting rate per $\mu \mathrm{Ci}{ }^{43} \mathrm{~K}$ so obtained was used to express the uptake from dialysis as $\mu \mathrm{Ci}^{43} \mathrm{~K}$ and hence as a percentage of the dialysate potassium. Three days later, before the next dialysis, the patients were monitored. After dialysis each patient was again monitored and the change in whole-body ${ }^{43} \mathrm{~K}$ counting rate gave the percentage loss of body potassium to the dialysate. The amount of ${ }^{43} \mathrm{~K}$ in the dialysate was also measured directly by comparing the counting rate from an aliquot of $4,000 \mathrm{ml}$ with that from a standard of identical geometry containing $1 \mu \mathrm{Ci}{ }^{43} \mathrm{~K}$. The samples were assayed with the whole-body monitor. The change in dialysate potassium concentration was also measured chemically.

\section{Results}

Data obtained for 15 non-dialysed patients are given in Table I. The patients' weight, height, and age were used to predict the "normal" value for body potassium which was plotted against the measured total body potassium as shown in Fig. 2. A paired Student's $t$ test showed no significant difference between the measured and the estimated normal values for the complete group $(P>0.05)$. However, there were significant differences $(P<0.05)$ in 5 of the 15 patients, the measured total body potassium being significantly less than the estimated normal value in Cases 5 and 12 and significantly greater in Cases 3, 6, and 7. The measurements, repeated three months later in Cases 6 and 7, were in good agreement (Table I).

The results for the 18 patients undergoing regular dialysis 
treatment are given in Table II. Analysis of the results was carried out in the same manner as for the non-dialysed patients (Fig. 3). In 14 of the 18 patients the measured values for total body potassium were not significantly different from the expected individual values nor for this group as a whole

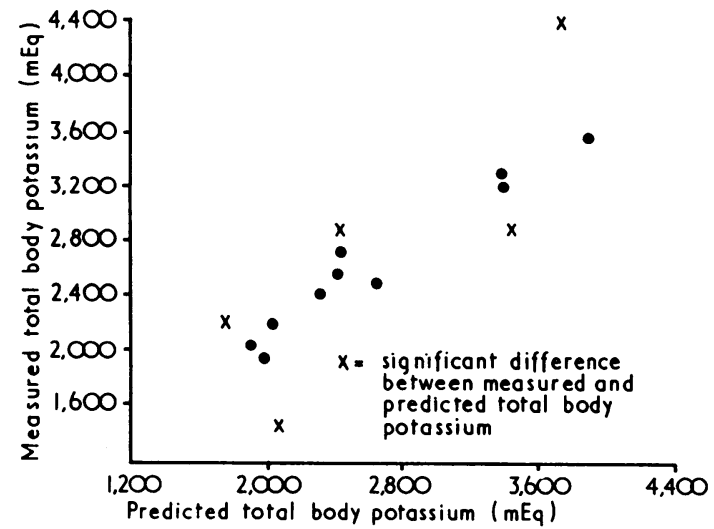

FIG. 2-Total body potassium: non-dialysed patients.

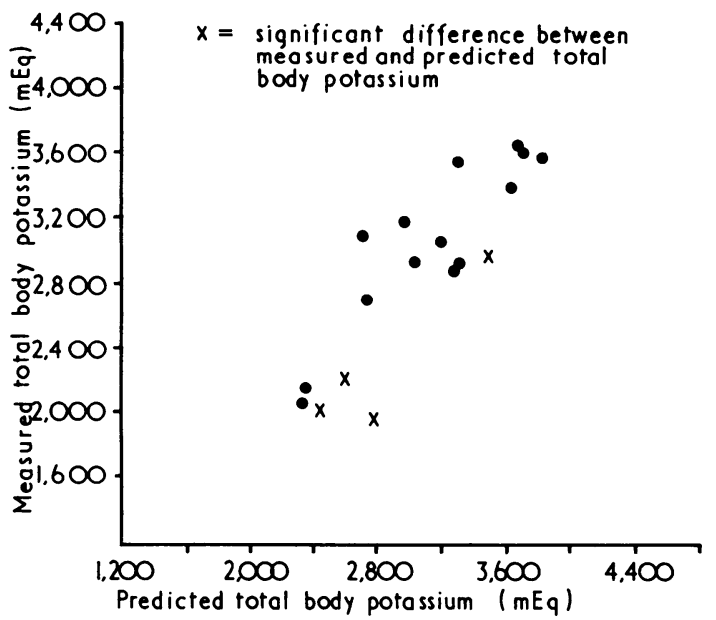

FIG. 3-Total body potassium: regular dialysis treatment patients.

( $P>0.05$ ). In four (Cases 26, 29, 30, and 33) the measured total body potassium was significantly less than the individual estimated values $(P<0.05)$, and if these results are included the difference between the measured and expected potassium values becomes significant for all 18 patients $(P<0.01)$.

Comparison of the measured body potassium values with corresponding normal values estimated from regression equations with only height and age as the independent variables confirmed the statistical significance of these findings (Boddy et al., 1972b).

The findings in the study of the bidirectional dynamic transfer of potassium during dialysis are summarized in Table III. The results were consistent in each patient and between the patients. Uptake of potassium from the dialysate was 30 and $32 \%$ representing 38 and $56 \mathrm{mEq} \mathrm{K}$ respectively at the concentration and dialysate volumes used. The loss of body potassium was 4.5$5.0 \%$ and good agreement was obtained between the results of

TABLE III-Potassium Kinetics during Dialysis

\begin{tabular}{|c|c|c|c|c|c|}
\hline \multirow{3}{*}{$\begin{array}{l}\text { Case } \\
\text { No. }\end{array}$} & \multicolumn{3}{|c|}{ Loss to Dialysate* } & \multirow{2}{*}{\multicolumn{2}{|c|}{$\begin{array}{l}\text { Uptake from Bath. } \\
\text { Whole-body Method }\end{array}$}} \\
\hline & \multirow{2}{*}{$\begin{array}{l}\text { Whole-body } \\
\text { Method } \\
\left(\%{ }^{\circ} \mathrm{K}\right)\end{array}$} & \multirow{2}{*}{$\begin{array}{c}\text { Dialysate } \\
\text { Method } \\
\left(\%^{42 \mathrm{~K}}\right) \\
\end{array}$} & \multirow{2}{*}{$\underset{(\operatorname{mEq~K})}{\text { Mean }}$} & & \\
\hline & & & & $\%{ }^{\bullet \cdot} \mathrm{K}$ & $\mathbf{m E q} \mathbf{K}$ \\
\hline $\begin{array}{l}27 \\
28\end{array}$ & $\begin{array}{l}4.53 \\
5.04\end{array}$ & $\begin{array}{l}4.46 \\
5.00\end{array}$ & $\begin{array}{l}160 \\
145\end{array}$ & $\begin{array}{l}29 \cdot 9 \\
32 \cdot 3\end{array}$ & $\begin{array}{l}38.1 \\
55.5\end{array}$ \\
\hline
\end{tabular}

- Loss to dialysate estimated chemically was 171 and $152 \mathrm{mEq} \mathrm{K}$ for Cases 27 and 28 sespectively. whole-body monitcring and radioactive and chemical assay of the dialysate. The loss to the dialysate was $160-145 \mathrm{mEq} \mathrm{K}+$ so that as a result of each dialysis the patients would be in negative balance by 122 and $89 \mathrm{mEq} \mathrm{K+}$ respectively-that is, 244 and $178 \mathrm{mEq} \mathrm{K}+/$ week. These patients were, however, on a restricted diet with an estimated intake of $30-45 \mathrm{mEq} \mathrm{K} /$ day or 210-315 mEq K/week (Table IV). When allowance was made for urinary and faecal $\mathrm{K}+$ loss, $\mathrm{K}+$ balance ranges of -63 to +42 $\mathrm{mEq}$ (Case 27) and +12 to $+117 \mathrm{mEq}$ (Case 28) per week were obtained.

TABLB IV-Approximate Potassium Balance per Week in Two Regular Dialysis Treatment Patients

\begin{tabular}{|c|c|c|c|c|c|c|c|}
\hline \multirow{2}{*}{$\begin{array}{l}\text { Case } \\
\text { No. }\end{array}$} & \multicolumn{3}{|c|}{ Intake (mEq K) } & \multicolumn{4}{|c|}{ Output (mEq K) } \\
\hline & Diet & Dialysis & Total & Urine & Faeces & Dialysis & Total \\
\hline 27 & $\begin{array}{l}210-315 \\
210-315\end{array}$ & $\begin{array}{r}76 \\
112\end{array}$ & $\begin{array}{l}286-391 \\
322-427\end{array}$ & $\begin{array}{l}12 \\
10\end{array}$ & $\begin{array}{l}17 \\
10\end{array}$ & $\begin{array}{l}320 \\
290\end{array}$ & $\begin{array}{l}349 \\
310\end{array}$ \\
\hline
\end{tabular}

Based on excreta assay over three-day period at time of study.

\section{Discussion}

The purpose of this study was to examine the potassium status of non-dialysed and dialysed patients with chronic renal failure under normal clinical conditions. No special attempt was made, therefore, to control diets rigorously. Indeed, it was considered of value to show that the potassuim status of the patient at the time of measurement could be determined routinely outside the milieu of an intensively controlled experiment.

Despite the potentially harmful consequences of abnormalities in potassium balance there is a paucity of studies reporting total body potassium levels in non-dialysed patients with chronic renal failure and their relation to normal levels of total body potassium. An exception is the study by Blainey and Hilton (1970), in which it was reported that total body potassium was low in patients with chronic renal failure before regular dialysis treatment began, but, unfortunately, the extent of depletion and the confidence levels were not indicated. The measured body potassium in the present patients as a group was not significantly different from the expected normal body potassium. The approximate potassium balance implies that these patients were able to excrete amounts of potassium equivalent to the dietary intake.

In two individuals (Cases 5 and 12) the total body potassium levels were significantly less than normal. Neither of these patients was on diuretic therapy nor was their urinary $\mathrm{K}^{+}$ excretion excessive. In fact, Cases 2, 3, 4, and 9, who had been receiving diuretics within the three months preceding this study, all had total body potassium levels not significantly different from their expected normal values. In three others (Cases 3, 6, and 7) body potassium was significantly greater than normal. To check that the measurements of body potassium were not simply fallacious, the determinations were repeated in Cases 6 and 7 and the results were in excellent agreement. This accords with previous experience of the reproducibility of measuring body potassium (Boddy et al., 1971) by the present method. The possibility exists that the normal range of total body potassium, related to the subject's weight, height, and age, is greater than found previously (Boddy et al., 1972b) but these measurements included more than 100 healthy male and female subjects whose weights ranged from 38 to $83 \mathrm{~kg}$, whose heights ranged from 151 to $192 \mathrm{~cm}$, and whose ages ranged from 18 to 77 years. The physical characteristics of the present patients were within these ranges and were not confined to a narrow band in the range of prediction.

To exclude the possible influence of aberrations in body weight, significant differences between the measured and estimated normal values for body potassium were confirmed by using a regression relation of body potassium on height and age (Boddy et al., 1972b). It is perhaps more likely, therefore, that 
total body potassium values greater than normal do sometimes occur in the presence of renal impairment as is suggested also by inspection of other findings (Morgan et al., 1970). Evidently there is a range of potassium status in non-dialysed patients with chronic renal failure; some having values within the normal range, others having values significantly greater or less than this range.

In dialysed patients there was also a range of potassium status (Table II) but in no individual was the total body potassium significantly greater than the estimated normal value, and in only 4 out of 18 individuals was it significantly less. Furthermore, as would be anticipated from the findings given earlier, there was no relation between the duration of regular dialysis treatment and total body potassium ( $r=0 \cdot 182)$ (Fig. 4). This suggests that in each of these four patients the total body potassium may have been low before starting regular dialysis treatment.

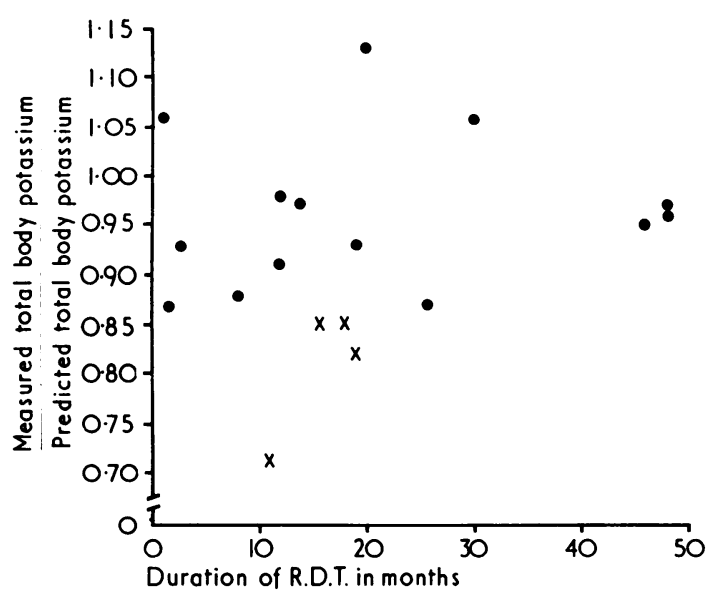

FIG. 4-Total body potassium with duration of dialysis.

Total body potassium was measured in 21 subjects undergoing treatment with a Kiil dialyser using a potassium concentration of $1.5 \mathrm{mEq} / \mathrm{l}$. by Morgan et al. (1970). The duration of dialysis was 30 hours/week for an average of nine months. Total body potassium in this group of patients was not significantly different from normal but body potassium in individual patients ranged from 79 to $133 \%$ of the expected normal value. Two patients measured within the first two months of dialysis were reported as having low normal values, which rose with increasing duration of dialysis. With dialysate potassium concentrations ranging from 1.5 to $2.7 \mathrm{mEq} / \mathrm{l}$. and twice-weekly dialysis no patient showed potassium depletion whether on a free diet or on a dietary intake of $70 \mathrm{mEq} \mathrm{K}+/$ day (Novak et al., 1969). In patients dialysed twice weekly against a potassiumfree fluid no potassium depletion was reported when they were on a free diet (Novak et al., 1969; W. J. Johnson et al., 1969). However, when the frequency of dialysis was thrice weekly a depletion was noted in 6 out of 13 cases dialysed against a potassium-free fluid (W. J. Johnson et al., 1969).

\section{POTASSIUM TRANSFER}

The bidirectional transfer of potassium between patient and dialysate is of importance in relation to potassium balance. However, previous estimations of this have been of limited accuracy. Estimation of loss of potassium to the bath by measuring total body potassium before and after dialysis (Novak et al., 1969; Johny et al., 1970; Morgan et al., 1970) is restricted primarily by counting statistics. The minimum detectable change is about $120-440 \mathrm{mEq}$, depending on the whole-body monitor, and the uncertainty in the estimated individual loss is $60-220 \mathrm{mEq}$. Measurement of differences in the concentration of stable potassium in the dialysate before and after dialysis involves errors which are "unacceptably large for precise quantitation" (Hayes and Robinson, 1965) but the present study suggests that these measurements are reliable when changes in dialysate $\mathrm{K}^{+}$are comparatively large. These technical difficulties are largely obviated by the use of the radioactive isotope ${ }^{43} \mathrm{~K}$.

Even when three to four days is allowed for equilibration with native $\mathrm{K}+$ the standard deviation due to counting statistics in a single measurement is only $0.3 \%$ or $10 \mathrm{mEq} \mathrm{K}$, and after this time the behaviour of ${ }^{43} \mathrm{~K}$ essentially represents that of native potassium (Corsa et al., 1950; Blainey et al., 1954; Flear et al., 1958; Talso et al., 1960; Remenchik and Miller, 1962; O'Toole et al., 1964; Hughes et al., 1967; J. E. Johnson et al., 1969). The agreement between the results of whole-body monitoring and direct measurement of the loss to the dialysate was encouraging and was within the limits of the counting statistics. The present estimates of 160 and $145 \mathrm{mEq} \mathrm{K}$ are in reasonable agreement with those of others, 124-163 mEq (Novak et al., 1969) and 150 $\mathrm{mEq}$ (Seedat, 1969), although the basis for the latter estimate was not explained. The mean loss found by Johny et al. (1970) of $220 \mathrm{mEq} \mathrm{K}$ was not significantly different from that found here, but the results ranged from a loss of $752 \mathrm{mEq}$ to a gain of $179 \mathrm{mEq}$. Morgan et al. (1970) found significant losses with a mean of $48 \mathrm{mEq} \mathrm{K}$, but the results of Hayes and Robinson (1965) were subject to such a large analytical error that no definite conclusions were drawn.

Uptake of potassium from dialysate amounted to 38 and 56 $\mathrm{mEq}$ in the present patients, giving deficits of 122 and $89 \mathrm{mEq}$ per dialysis or 244 and $178 \mathrm{mEq} /$ week. Total body potassium in these two patients was not significantly different from the predicted normal value, which suggests that they were approximately in balance. This would be expected also from the estimated balance given in Table IV and shown diagrammatically in Fig. 5 where the urine and faecal output were measured in
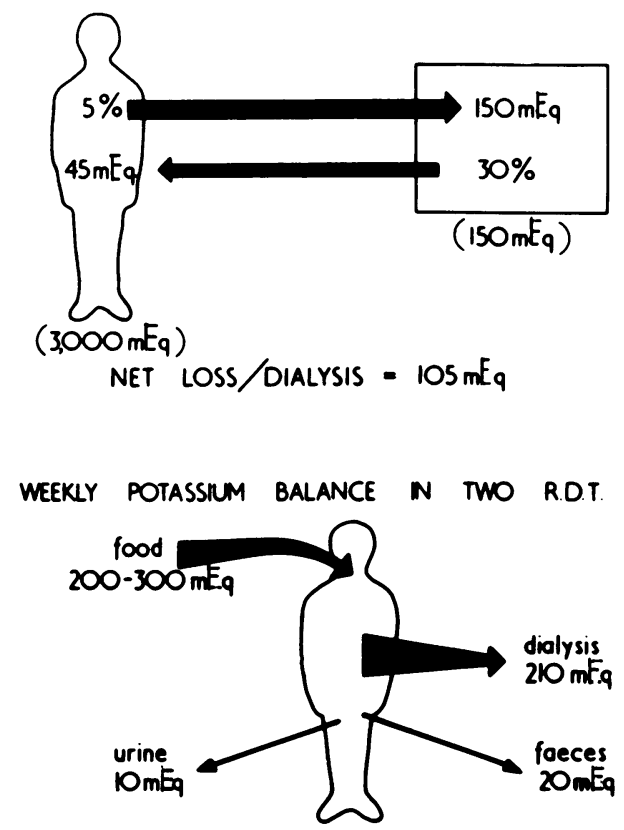

FIG. 5-Potassium kinetics during dialysis.

samples obtained from these patients. The potassium loss by urine and faeces in these two dialysed patients is very small when compared with the loss to dialysate. This seems to be true for the group of patients as the daily urinary potassium loss of a number of the dialysed patients in this study has subsequently been found to be in the range of $1.3-22 \mathrm{mEq}$ (mean $6.2 \mathrm{mEq}, \mathrm{n}=14$ ). 
The daily faecal loss was found to be in the range of 1.4-18 $\mathrm{mEq}$ (mean $5.7 \mathrm{mEq}, \mathrm{n}=8$ ). Thus there may be a large variation in faecal losses, and values as high as $26 \mathrm{mEq} / 24$ hours have been recorded (Hayes and Robinson, 1965). Nevertheless, such losses are still small in comparison with the loss to the dialysate which, together with dietary intake, is the major factor in the potassium balance of the regular dialysis patient.

The present study shows that there is a wide range of potassium status in patients with chronic renal failure being maintained with haemodialysis and it is possible that this is, at least in part, related to the variation in potassium status found among non-dialysed patients with chronic renal failure. The absence of a positive relation between the duration of regular dialysis treatment and the total body potassium, together with the balance studies in two patients, indicates that twice-weekly dialysis against a dialysate potassium content of $1 \mathrm{mEq} / \mathrm{l}$. is compatible with the maintenance of potassium balance. A significant advantage of examining potassium status by wholebody monitoring with reference to a normal control group is the simplicity, involving only a single measurement in the patient, and quantification of the degree of abnormality.

We wish to thank Professor $\mathrm{H}$. W. Wilson for his interest and encouragment. This study was supported, in part, by a grant from the Scottish Hospital Endowments Research Trust which is gratefully acknowledged.

\section{References}

Blainey, J. D., Cooke, W. T., Quinton, A., and Scott, K. W. (1954). Clinical Science, 13, 165

Blainey, J. D., and Hilton, D. D. (1970). Annals of The Royal College of Surgeons of England, 47,45

Boddy, K. (1967). British fournal of Radiology, 40, 631.

Boddy, K., King, P. C., Lindsay, R. M., Winchester, G., and Kennedy, A. C., (1972a) British Medical fournal, 1, 140.

Boddy, K., King, P. C., Hume, R., and Weyers E. (1972b). Fournal of Clinical Pathology. In press.

Boddy, K., King, P. C., Tothill, P., and Strong, J. A. (1971). Physics in Medicine and Biology, 16, 275.

Corsa, L., Olney, J. M., Steenburg, R. W., Ball, M. R., and Moore, F. D. (1950). Fournal of Clinical Investigation, 29, 1280

Flear, C. T. G., Cawley, R., Cooke, W. T., and Quinton, A. (1958). Clinical Science, 17, 105.

Hayes, C. P., and Robinson, R. R. (1965). Transactions. American Society for Artificial Internal Organs, 11, 242

Hughes, D., Williams, R. E., and Smith, A. H. (1967). Clinical Science, 32,

Johnson, J. E., Hartsbuck, J. M., Zollinger, R. M., and Moore, F. D. (1969). Metabolism, 18, 663.

Johnson, W. J., Frohnert, P. P., and Novak, L. P. (1969). Paper read at IV International Congress of Nephrology (Stockholm)

Johny, K. V., Lawrence, J. R., O'Halloran, M. W., Wellby, M. L., and Worthley, B. M. (1970). Nephron, 7, 230.

Moore, F. D., et al., (1954). Metabolism, 3, 334

Morgan, A. G., Burkinshaw, L., Robinson, P. J. A., and Rosen, S. M. (1970) British Medical fournal, 1, 779 .

Novak, L. P., Frohnert, P. P., and Johnson, W. J. (1969). Paper read at IV International Congress of Nephrology (Stockholm)

O'Toole, J. J., Peterson, R. E., and Weiner, E. V. (1964). Metabolism, 13, 116. Whole Body Counting, I.A.E.A., Vienna, p. 331. London, H.M.S.O. Whole Body Counting, I.A.E.A., Vienna, p. 331.
.

Talso, P. J., Miller, C. E., Carballo, A. J., and Vasquez, I. (1960). Metabolism, 9, 456 .

\title{
Plasma and Urinary Luteinizing Hormone Levels in the Diagnosis of Endocrine Disease
}

\author{
R. WIKRAMANAYAKE， J. R. KEENAN， G. S. SPATHIS， J. D. N. NABARRO， P. J. LEONARD, \\ M. J. GALLAGHER
}

British Medical fournal, 1972, 1, 775-778

\section{Summary}

The diagnostic value of measurements of plasma and urinary luteinizing hormone (LH) has been studied in 209 patients with endocrine disease. In 44 patients puberty was either delayed or had failed to occur. In those with chromosomal abnormalities the LH levels were often within the normal range, whereas those with a pituitary cause usually had low levels. In boys with delayed puberty plasma LH levels rose before physical changes occurred and had prognostic value. In patients with later gonadal failure, men with impotence or infertility, and women with secondary amenorrhoea LH assays proved of little value, although in one case a premature menopause was suspected and six patients with anorexia nervosa had low LH levels.

Edgware General Hospital, Edgware, Middlesex

R. WIKRAMANAYAKE, M.D., M.R.C.P., Locum Consultant Physician

Central Middlesex Hospital, London N.W.10

J. R. KEENAN, M.B., M.R.C.PATH., Consultant Chemical Pathologist

St. Helier Hospital, Carshalton, Surrey

G. S. SPATHIS, D.M., M.R.C.P., Consultant Physician

Middlesex Hospital, London W.1

J. D. N. NABARRO, M.D., F.R.C.P., Consultant Physician

Searle Scientific Services, High Wycombe, Bucks.

P. J. LEONARD, M.SC., M.R.C.PATH., Director of Clinical Chemistry M. J. GALLAGHER, B.SC., PH.D., Biochemist
Sixty patients with disorders of the hypothalamicpituitary area were studied. Levels of LH were measured and considered in relation to the other anterior pituitary hormones. Impairment of LH secretion was one of the first effects on hormone production of disease affecting this area, and this was, of course, most readily detected in postmenopausal women.

The normal ranges of both plasma and urine $L H$ are wide and there seems to be considerable day-to-day variation, especially of urinary output. Several samples should, therefore, be measured if therapeutic decisions are involved.

\section{Introduction}

Knowledge of the levels of follicle-stimulating hormone (FSH) and luteinizing hormone (LH) in plasma or urine is likely to be of value in the diagnosis of a number of patients with endocrine disease. These include patients with delayed sexual maturation, deciding whether it is hypothalamic-pituitary or gonadal in origin and also whether there is just delay or probable failure of gonadotrophin secretion. Gonadotrophin assays may also help in the evaluation of patients with secondary failure of sexual function, secondary amenorrhoea in women, and impotence or infertility in men. Thirdly, gonadotrophin measurements should complement assays of corticotrophin, thyrotrophin, and growth hormone in the assessment of hypothalamicpituitary function.

Methods have now been described for measuring the plasma and urinary concentrations of FSH and of LH (Franchimont, 1970; Lipsett et al., 1970). FSH measurements present considerable practical difficulties but an LH assay has recently been 